\title{
Influence of different width/height ratio of maxillary anterior teeth in the attractiveness of gingival smiles
}

\author{
Ana Carolina Guimarães Borges', Mayra Reis Seixas², Andre Wilson Machado ${ }^{3}$
}

\begin{abstract}
Objective: To evaluate, among laypersons and orthodontists, the influence of the width/height proportions of upper anterior teeth on the smile attractiveness, in photographs of close up smile from three adult Caucasian women, with $4 \mathrm{~mm}$ of gingival exposure. Methods: The photographs of close up smiles were digitally manipulated and six images were created from each smile with teeth's width/height proportions in $65 \%, 70 \%, 75 \%, 80 \%, 85 \%$ and $90 \%$. Then, all these images were manipulated again and a black mask covering all teeth from the lower arch was created. The figures were then assessed by 60 evaluators, 30 orthodontists and 30 laypersons, who assigned, in a visual analog scale, the level of attractiveness of each image. Results: The obtained results, in general, showed that the proportions of $75 \%, 80 \%$ and $85 \%$ received the highest scores while the proportion of $65 \%$ received the lowest scores, for both groups of examiners $(\mathrm{p}<0.05)$. When orthodontists and laypersons were compared, it was not found, in most situations, a significant statistical difference between their assessments ( $p>0.05)$. Yet, the comparison between scores assigned to smiles with and without inferior teeth showed that, for all situations, there was no statistically significant difference between them ( $\mathrm{p}>0.05$ ). Conclusion: For patients with gingival smile, the width/height proportions of upper anterior teeth considered more esthetic were the ones of $75 \%, 80 \%$ and $85 \%$ for laypersons and orthodontists, and the presence or absence of inferior teeth did not affect the attractiveness level of the assessed smiles.
\end{abstract}

Keywords: Smile. Dental esthetic. Gingiva.

Objetivo: avaliar, entre leigos e ortodontistas, a influência da alteração das proporções largura/altura dos dentes anterossuperiores na atratividade do sorriso, em fotografias do sorriso aproximado de três mulheres leucodermas adultas, com $4 \mathrm{~mm}$ de exposição gengival. Métodos: as fotografias dos sorrisos aproximados foram manipuladas em computador e seis imagens foram criadas para cada sorriso com as proporções largura/altura dos dentes em 65\%, 70\%, 75\%, 80\%, 85\% e 90\%. Em seguida, todas essas imagens foram novamente manipuladas e criou-se uma máscara preta cobrindo todos os dentes da arcada inferior. As imagens foram, então, julgadas por 60 avaliadores, 30 ortodontistas e 30 leigos, que aferiram, em uma escala visual analógica, o nível de atratividade de cada imagem. Resultados: os resultados encontrados, em geral, demonstraram que as proporções de $75 \%, 80 \%$ e $85 \%$ receberam as maiores notas enquanto a de $65 \%$ recebeu as menores notas, para os dois grupos de examinadores ( $<<0,05)$. Quando os ortodontistas e leigos foram comparados, não foi encontrada, na grande maioria das situações, diferença estatística significativa entre seus julgamentos ( $>0,05)$. Ainda, a comparação entre as notas aferidas aos sorrisos com e sem os dentes inferiores mostrou que, para todas as situações, não houve diferença estatisticamente significativa entre elas ( $p>0,05$ ). Conclusão: para pacientes com sorriso gengival, as proporções largura/altura dos dentes anterossuperiores consideradas mais estéticas foram as de $75 \%, 80 \%$ e $85 \%$ para leigos e ortodontistas, e a presença ou não dos dentes inferiores não influenciou no nível de atratividade dos sorrisos pesquisados.

Palavras-chave: Sorriso. Estética dentária. Gengiva.

${ }^{1}$ Specialist in Orthodontics, UFBA.

${ }^{2}$ MSc in Orthodontics, UFRJ. Diplomate by the Brazilian Board of Orthodontics. ${ }^{3}$ Associate Professor of Orthodontics, UFBA; PhD in Orthodontics, UNESP/UCLA. MSc in Orthodontics, PUC-Minas. Associate Professor in the MSc Program of Orthodontics - UCLA-EUA.

How to cite this article: Borges ACG, Seixas MR, Machado AW. Influence of different width/height ratio of maxillary anterior teeth in the attractiveness of gingival smiles. Dental Press J Orthod. 2012 Sept-Oct;17(5):115-22.

\begin{abstract}
Submitted: Marh 31, 2012 - Revised and accepted: May 31, 2012
» The authors report no commercial, proprietary or financial interest in the products or companies described in this article.

" Patients displayed in this article previously approved the use of their facial and intraoral photographs.
\end{abstract}

Contact address: Andre Wilson Machado

Av. Araújo Pinho, 62 - $7^{\circ}$ Andar - Canela, Salvador/BA - Brazil

Zip code: 40.110-150 - E-mail: awmachado@gmail.com 


\section{INTRODUCTION}

Nowadays, the number of adults seeking esthetic treatment is high. Many times inspired by beautiful smiles of artists from the media, patients show more and more interest in treatments that improve the smile's esthetic. ${ }^{1}$ Generally, the literature suggests that the ideal smile should not present gingival exposure $^{2-6}$ or only little exposure of this tissue..$^{7-10}$ Although this information is well accepted in literature, a quantification of this little gingival exposure is a point of great scientific and clinical discussion. How many millimeters of gingival exposure will be considered non- esthetic?

The classic work published by Kokich et $\mathrm{al}^{11}$ showed that smiles with gingival exposure of $4 \mathrm{~mm}$ were considered, by laypersons, less attractive. Recent studies confirm these findings, showing that large levels of gingival exposure on the smile are highly detrimental to the smile's esthetic. ${ }^{12,13,22}$

This way, one can observe the need to treat the gingival smile to optimize the esthetic result of orthodontic treatments. This problem presents multifactorial etiology such as: Maxillary vertical excess, hyperactivity and reduced length of superior lip and changes on the heights of the upper anterior teeth's clinical crowns. ${ }^{14}$ And therefore, the treatment is quite diversified.

From a clinical view, due to the need for individualization of the esthetic parameters for patients with gingival smile, the following questioning can be made: Would gingival smile patients, already considered non-esthetic, have as width/height ideal proportion of upper anterior teeth, the same as patients with ideal smiles? In other words, could the modification of width/height proportion of upper anterior teeth affect the attractiveness of these smiles?

These questioning came up because, after orthodontic treatment of some patients, increasing the size of upper anterior teeth by cosmetic increment of the incisal edges, it was noticed a possible disguise of the gingival smile. Actually, patients reported a sense of reduction on the amount of gingival exposure.

Beside this aspect, it is known that modifying the width/height proportion of upper anterior teeth, the level of exposure of inferior teeth may also be altered. Thus, another question arises: Does the modification of width/height proportion of upper anterior teeth, exposing more or less the inferior teeth, affect the level of attractiveness of the smile's esthetic?

These questions were explored in this study which objective was to evaluate the influence of altering width/height proportions of upper anterior teeth on the attractiveness of three female smiles with $4 \mathrm{~mm}$ of gingival exposure.

\section{MATERIAL AND METHODS}

A photograph of close up smile was used from three adult Caucasian women between 25 and 33 years old. The selected photographs had good smile's esthetic, absence of restoration procedures on upper anterior teeth and presented a minimum gingival smile of $4 \mathrm{~mm}$.

After selection, images were edited and manipulated with the aid of Adobe ${ }^{\circledR}$ Photoshop ${ }^{\circledR}$ software CS4 (Seattle, USA). Initially they were paired to assure visualization in magnification of 1:1, i.e., during assessment, one millimeter on the image was equivalent to one millimeter on the real patients. For that, it was used the measurement of the clinical crown's height of the upper central incisors from the study model.

Then, the images were edited to correct brightness, contrast, color adjustment and removal of eventual stains or marks that could affect the assessment process. Also, one side of the smile was selected for maintenance and/or creation of some inclusion criteria such as: (A) Gingival exposure of $4 \mathrm{~mm} ;{ }^{11}$ (B) leveled gingival margins of canine and central incisor; ${ }^{15,16}(\mathrm{C})$ gingival margin of lateral incisor $0.5 \mathrm{~mm}$ below margin of central and canine ${ }^{11}$; (D) incisal edge of lateral incisor $1 \mathrm{~mm}$ above the central incisor edge; ${ }^{17}$ (E) central incisor length of $10 \mathrm{~mm}$ and width of $8 \mathrm{~mm}$ creating a height/width proportion of $80 \% ;^{18}$ (F) adequate smile curvature with the edges of upper anterior teeth contouring the lower lip. ${ }^{16}$ This way, three new images were created, one for each patient, and called standard images.

These images were then manipulated to create different proportions of upper anterior teeth. For the first proportion, of $80 \%$, the image was mirrored creating perfectly symmetric sides. Five new width/ height proportions of central incisors were created: $65 \%, 70 \%, 75 \%, 85 \%$ and $90 \%$. For that, based on these proportions, the central incisor length of one side was altered (increased or reduced) and lateral 
and canines were also modified (in same magnification) to maintain the characteristics previously described. These five new images were also mirrored to maintain the images' symmetry eliminating another possible bias in the assessment.

As a result of this process, six images were created, with six different width/height proportions of upper anterior teeth, for each patient, totaling 18 images (Fig 1).
All images were manipulated once again to remove lower teeth creating a black mask over this region (Fig 2) totaling another 18 images. From that it was possible to evaluate, initially, the different width/ height proportions considering different levels of lower teeth exposure and then excluding this variable.

After this process, an album was assembled, with six sheets, in photographic paper Fujicolor Crystal Archive Paper $^{\odot}$ (Fujifilm do Brasil Ltda., Manaus, Brazil)
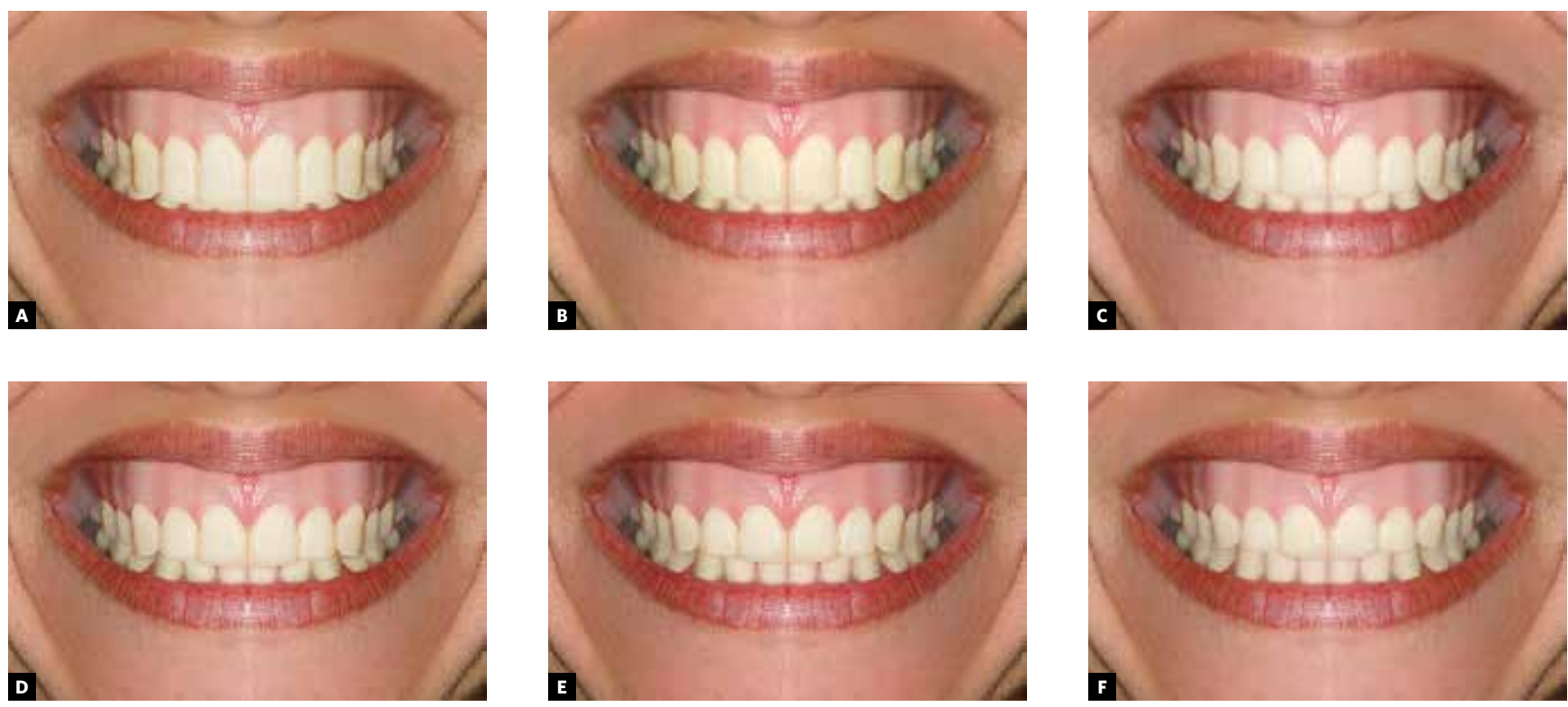

Figure 1 - Example of figures diagramming, for one of the used smiles, with the six width/height proportions assessed, displaying inferior teeth: A) 65\%; B) $70 \%$; C) $75 \%$; D) $80 \%$; E) $85 \%$ and F) $90 \%$
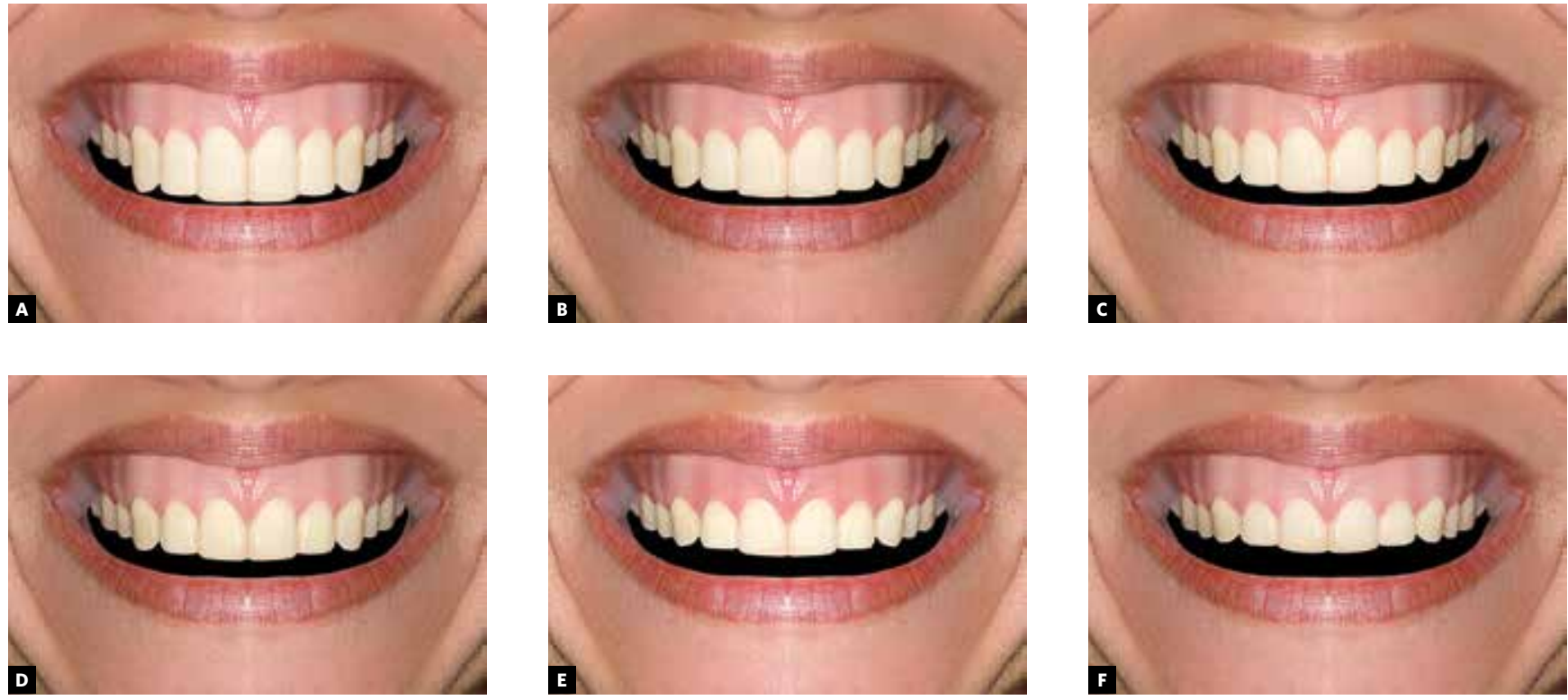

Figure 2 - Example of figures diagramming, for one of the used smiles, with the six width/height proportions assessed, without displaying inferior teeth (black mask): A) 65\%; B)70\%; C)75\%; D) $80 \%$; E) $85 \%$ and F) $90 \%$. 
size A4 $(21.0 \mathrm{~cm} \times 29.7 \mathrm{~cm})$. Each sheet displayed the six smile images, of the same patient, with the different proportions. The images disposition was randomly defined, by draw, given that each patient presented the sequence of six smiles photos displaying all teeth followed by the photos of the same smiles, now with the mask.

The images were subjected to assessment from 30 orthodontists properly enrolled at the Brazilian Association of Orthodontics and Facial Orthopedics and 30 lay people, with graduate level for evaluation of the attractiveness level of each image. Along with the album, each evaluator received a form containing printed simulations with visual analog scales (VAS).

The scales were configured presenting an ascending order of quality from the left to the right. To each evaluator it was explained that it was possible to mark the point in any region of the rule. The visual analog scales ${ }^{12,13,19,22,25,26}$ had $10 \mathrm{~cm}$ and on the left end it was written "VERY BAD" and on the right end "VERY GOOD". The center was marked to give the evaluator the notion of regular.

After images analysis, the distance between the mark assigned by the evaluator and the left end in all scales, was measured with a digital caliper rule

Table 1 - Mean and standard deviation of patient's 1 smile attractiveness level with presence of inferior teeth.

\begin{tabular}{|c|c|c|c|c|c|c|c|}
\hline \multirow{2}{*}{ Overbite Smile } & \multicolumn{3}{|c|}{ Orthodontists } & \multicolumn{3}{|c|}{ Laypersons } & \multirow{2}{*}{ Difference } \\
\hline & Mean & SD & Results ${ }^{\star}$ & Mean & SD & Results* & \\
\hline $65 \%$ & 20.05 & 10.92 & C & 38.55 & 21.23 & $B$ & \\
\hline $70 \%$ & 28.86 & 14.13 & B & 46.31 & 22.03 & A. B & \\
\hline $75 \%$ & 40.15 & 17.35 & A & 45.91 & 22.07 & A. B & $\star \star$ \\
\hline $80 \%$ & 38.94 & 20.18 & A & 54.32 & 18.58 & $A$ & \\
\hline $85 \%$ & 34.6 & 18.46 & A. B & 46.00 & 18.56 & A. B & \\
\hline $90 \%$ & 28.47 & 17.51 & B & 40.89 & 17.69 & $B$ & \\
\hline
\end{tabular}

*Smiles with the same letters do not differ $(p<0.05)$. * Statistically significant difference between the two groups of evaluators $(p<0.05)$.

Table 2 - Mean and standard deviation of patient's 2 smile attractiveness level with the presence of inferior teeth.

\begin{tabular}{|c|c|c|c|c|c|c|c|}
\hline \multirow{2}{*}{ Overbite Smile } & \multicolumn{3}{|c|}{ Orthodontists } & \multicolumn{3}{|c|}{ Laypersons } & \multirow{2}{*}{ Difference } \\
\hline & Mean & SD & Results* & Mean & SD & Results* & \\
\hline $65 \%$ & 22.88 & 15.84 & B & 34.36 & 24.99 & $B$ & \\
\hline $70 \%$ & 32.30 & 19.57 & A. B & 45.17 & 21.83 & A. B & \\
\hline $75 \%$ & 38.79 & 18.91 & $A$ & 55.19 & 19.52 & $A$ & \\
\hline $80 \%$ & 36.02 & 20.06 & $A$ & 48.01 & 16.44 & A. B & \\
\hline $85 \%$ & 38.59 & 22.16 & $A$ & 51.95 & 16.67 & $A$ & \\
\hline $90 \%$ & 35.83 & 20.90 & $A$ & 44.87 & 16.64 & A. B & $\star \star$ \\
\hline
\end{tabular}

*Smiles with the same letters do not differ $(p<0.05) .{ }^{\star \star}$ Statistically significant difference between the two groups of evaluators $(p<0.05)$.

Table 3 - Mean and standard deviation of patient's 3 smile attractiveness level with the presence of inferior teeth.

\begin{tabular}{|c|c|c|c|c|c|c|c|}
\hline \multirow{2}{*}{ Overbite Smile } & \multicolumn{3}{|c|}{ Orthodontists } & \multicolumn{3}{|c|}{ Laypersons } & \multirow{2}{*}{ Difference } \\
\hline & Mean & SD & Results * & Mean & SD & Results* & \\
\hline $65 \%$ & 24.39 & 15.05 & C & 23.96 & 19.57 & B & \\
\hline $70 \%$ & 30.38 & 15.88 & B. $C$ & 34.60 & 21.77 & A. B & \\
\hline $75 \%$ & 35.32 & 17.05 & A. B & 43.81 & 24.85 & $A$ & \\
\hline $80 \%$ & 44.83 & 16.53 & $A$ & 44.66 & 24.87 & A & \\
\hline $85 \%$ & 40.73 & 17.41 & A. B & 39.14 & 19.07 & $A$ & \\
\hline $90 \%$ & 35.40 & 17.40 & A. B & 37.83 & 24.32 & A & \\
\hline
\end{tabular}

${ }^{\star}$ Smiles with the same letters do not differ $(p<0.05) .{ }^{\star \star}$ There was no statistically significant difference between orthodontists and laypersons ( $\left.<<0.05\right)$. 
Zeusan ${ }^{\circledR}$ (Zeusan, Campinas, Brazil) and were used as measure, in millimeters, of the attractiveness level of each assessed image corresponding to each evaluator's score. ${ }^{12,13}$ The data from each survey were compiled in a spread sheet, using Minitab software version $14{ }^{\circledR}$ (Minitab Inc., State College, EUA), and received statistical treatment. It was applied ANOVA test and Tukey post test to perform comparison between smiles with different proportions. For comparison between both groups of evaluators and between smiles with and without the black mask, student $t$ test was used. For all analysis, a significant level of $5 \%$ was used

\section{RESULTS}

On Table 1, it is possible to observe mean and standard deviation of orthodontists' and laypersons' assessment for the smile of patient 1 . According to orthodontists, the scores assigned to smiles with proportions of $75 \%, 80 \%$ and $85 \%$ were the highest ones and did not show statistically significant difference with one another. The proportion of $65 \%$, on the other hand, obtained the lowest scores. According to laypersons' opinion the highest scores were the proportions $70 \%, 75 \%, 80 \%$ and $85 \%$ and they did not show statistically significant difference with one another. The proportions of $65 \%$ and $90 \%$ presented the lowest scores.

Table 4 - Mean and standard deviation of patient's 1 smile attractiveness level with and without black mask covering the lower teeth, for both groups of evaluators.

\begin{tabular}{|c|c|c|c|c|c|c|c|c|c|c|}
\hline \multirow{2}{*}{$\begin{array}{l}\text { Different } \\
\text { proportions }\end{array}$} & \multicolumn{2}{|c|}{$\begin{array}{l}\text { Overbite Smile } \\
\text { Orthodontist }\end{array}$} & \multicolumn{2}{|c|}{$\begin{array}{c}\text { With black mask } \\
\text { Orthodontist }\end{array}$} & \multirow[t]{2}{*}{$\mathbf{p}$} & \multicolumn{2}{|c|}{$\begin{array}{l}\text { Overbite Smile } \\
\text { Laypersons }\end{array}$} & \multicolumn{2}{|c|}{$\begin{array}{c}\text { With black mask } \\
\text { Laypersons }\end{array}$} & \multirow[t]{2}{*}{$\mathbf{p}$} \\
\hline & Mean & SD & Mean & SD & & Mean & SD & Mean & SD & \\
\hline $65 \%$ & 20.05 & 10.92 & 25.60 & 16.22 & 0.126 & 38.55 & 21.23 & 31.67 & 22.05 & 0.223 \\
\hline $70 \%$ & 28.86 & 14.13 & 25.78 & 16.44 & 0.440 & 46.31 & 22.03 & 47.89 & 22.84 & 0.786 \\
\hline $75 \%$ & 40.15 & 17.35 & 35.35 & 19.72 & 0.321 & 45.91 & 22.07 & 50.42 & 21.28 & 0.424 \\
\hline $80 \%$ & 38.94 & 20.18 & 41.41 & 18.57 & 0.623 & 54.32 & 18.58 & 52.94 & 16.85 & 0.764 \\
\hline $85 \%$ & 34.6 & 18.46 & 39.13 & 21.39 & 0.384 & 46.00 & 18.56 & 47.86 & 17.55 & 0.692 \\
\hline $90 \%$ & 28.47 & 17.51 & 30.93 & 15.06 & 0.562 & 40.89 & 17.69 & 41.40 & 22.97 & 1.000 \\
\hline
\end{tabular}

Table 5 - Mean and standard deviation of patient's 2 smile attractiveness level with and without black mask covering the lower teeth, for both groups of evaluators.

\begin{tabular}{|c|c|c|c|c|c|c|c|c|c|c|}
\hline \multirow{2}{*}{$\begin{array}{c}\text { Different } \\
\text { proportions }\end{array}$} & \multicolumn{2}{|c|}{$\begin{array}{c}\text { Overbite Smile } \\
\text { Orthodontist }\end{array}$} & \multicolumn{2}{|c|}{$\begin{array}{c}\text { With black mask } \\
\text { Orthodontist }\end{array}$} & \multirow[t]{2}{*}{$\mathbf{p}$} & \multicolumn{2}{|c|}{$\begin{array}{c}\text { Overbite Smile } \\
\text { Laypersons }\end{array}$} & \multicolumn{2}{|c|}{$\begin{array}{l}\text { With black mask } \\
\text { Laypersons }\end{array}$} & \multirow[t]{2}{*}{$\mathbf{p}$} \\
\hline & Mean & SD & Mean & SD & & Mean & SD & Mean & SD & \\
\hline $65 \%$ & 22.88 & 15.84 & 26.18 & 17.95 & 0.453 & 34.36 & 24.99 & 48.18 & 23.59 & 0.032 \\
\hline $70 \%$ & 32.30 & 19.57 & 31.10 & 22.36 & 0.825 & 45.17 & 21.83 & 53.26 & 22.60 & 0.164 \\
\hline $75 \%$ & 38.79 & 18.91 & 42.10 & 19.04 & 0.503 & 55.19 & 19.52 & 60.05 & 18.40 & 0.325 \\
\hline $80 \%$ & 36.02 & 20.06 & 42.72 & 21.74 & 0.220 & 48.01 & 16.44 & 54.76 & 17.92 & 0.134 \\
\hline $85 \%$ & 38.59 & 22.16 & 36.17 & 20.47 & 0.661 & 51.95 & 16.67 & 52.33 & 17.87 & 0.932 \\
\hline $90 \%$ & 35.83 & 20.90 & 35.97 & 17.83 & 0.979 & 44.87 & 16.64 & 42.37 & 18.73 & 0.586 \\
\hline
\end{tabular}

Table 6 - Mean and standard deviation of patient's 3 smile attractiveness level with and without black mask covering the lower teeth, for both groups of evaluators.

\begin{tabular}{|c|c|c|c|c|c|c|c|c|c|c|}
\hline \multirow{2}{*}{$\begin{array}{c}\text { Different } \\
\text { proportions }\end{array}$} & \multicolumn{2}{|c|}{$\begin{array}{l}\text { Overbite Smile } \\
\text { Orthodontist }\end{array}$} & \multicolumn{2}{|c|}{$\begin{array}{c}\text { With black mask } \\
\text { Orthodontist }\end{array}$} & \multirow[t]{2}{*}{$\mathbf{p}$} & \multicolumn{2}{|c|}{$\begin{array}{c}\text { Overbite Smile } \\
\text { Laypersons }\end{array}$} & \multicolumn{2}{|c|}{$\begin{array}{c}\text { With black mask } \\
\text { Laypersons }\end{array}$} & \multirow[t]{2}{*}{$\mathbf{p}$} \\
\hline & Mean & SD & Mean & SD & & Mean & SD & Mean & SD & \\
\hline $65 \%$ & 24.39 & 15.05 & 26.15 & 12.26 & 0.622 & 23.96 & 19.57 & 33.80 & 21.53 & 0.069 \\
\hline $70 \%$ & 30.38 & 15.88 & 28.15 & 16.80 & 0.618 & 34.60 & 21.77 & 43.34 & 22.32 & 0.130 \\
\hline $75 \%$ & 35.32 & 17.05 & 41.78 & 18.51 & 0.205 & 43.81 & 24.85 & 50.47 & 23.09 & 0.287 \\
\hline $80 \%$ & 44.83 & 16.53 & 46.02 & 16.88 & 0.783 & 44.66 & 24.87 & 55.29 & 18.68 & 0.067 \\
\hline $85 \%$ & 40.73 & 17.41 & 49.28 & 18.27 & 0.068 & 39.14 & 19.07 & 48.21 & 23.01 & 0.059 \\
\hline $90 \%$ & 35.40 & 17.40 & 43.48 & 18.75 & 0.089 & 37.83 & 24.32 & 44.90 & 24.36 & 0.265 \\
\hline
\end{tabular}


On Table 2, shows the mean and standard deviation of orthodontists' and laypersons' assessment for the smile of patient 2 . According to orthodontists and laypersons, the scores assigned to smiles with proportions of $70 \%, 75 \%, 80 \%, 85 \%$ and $90 \%$ were the highest ones and did not show statistically significant difference with one another. The proportion of $65 \%$ on the other hand obtained the lowest scores.

On Table 3, it is observed the ratings' mean and standard deviation assigned by orthodontists and laypersons for the smile of patient 3 . According to orthodontists, the scores assigned to smile with proportions of $75 \%, 80 \%, 85 \%$ and $90 \%$ were the highest ones and did not have statistically significant difference with one another. The proportion of $65 \%$ on the other hand had the lowest scores. According to laypersons' opinion the highest scores were the proportions $70 \%, 75 \%, 80 \%, 85 \%$ and $90 \%$ and they did not have statistically significant difference with one another. The proportion of $65 \%$ presented the lowest score.

The comparison between orthodontists' and laypersons' opinion regarding patients' 1,2 and 3 smiles, showed that from a total of 18 analyses, 16 did not have statistically significant difference. Only for patient 1 , at a proportion of $75 \%$ and for patient 2 , at a proportion of $90 \%$ these scores revealed statistically significant difference, with laypersons assigning higher scores than orthodontists. Tables 4, 5, 6 show student's $t$ test, applied to compare the smiles with and without display of lower arch teeth, using a black mask to cover them. It is possible to observe that for all situations there was no statistically significant difference between the scores assigned to the two types of assessed smiles.

\section{DISCUSSION}

Cosmetic dentistry concepts present several considerations about the dental proportion and morphology. The width/height proportion considered as "gold standard" determines that the width of superior central incisors must be of approximately $80 \%$ of its height, with accepted variation between $75 \%$ to $85 \% .^{15,16,18}$ However these proportions were established for ideal smiles, with no gingival exposure when smiling.

The analysis of the present study showed that the proportions of $75 \%, 80 \%$ and $85 \%$, received the highest scores, from laypersons and orthodontists for the three assessed smiles. The hypothesis raised previously in this research, that longer teeth, i.e. with smaller width/height proportions (65\% and 70\%), would be capable of disguising the excessively gingival smile was not accepted. The clinical impact on these data is that the specialties directly related to cosmetics, such as Restorative Dentistry and Dental Prosthesis will not have great results on the masking of gingival smile. The increase of white esthetic, i.e., resin increments or longer upper anterior prosthesis, aiming to increase the dental length (reducing the width/ height proportion), according to our results would not be capable to disguise the gingival excess. It is suggested for patients with gingival smile a specific approach to the gingival tissue, that affect directly the problem: The amount of exposed gingiva. This approach is multidisciplinary and may involve Periodontics, when it is identified gingival excess on probing, having as solution the procedure of gingivectomy. In cases of maxillary vertical excess, the problem's solution involves orthognathic surgery and in cases of interrelation with esthetic medicine, in which the problem's etiology may be associated to hyperactivity of muscles responsible for the upper lip elevation during smile. ${ }^{14}$ In these cases some procedures are available, among them is the use of silicone at the bottom of the vestibule, the infiltration of Botulinic toxin and resection procedures on the muscles responsible for the upper lip mobility. ${ }^{20,21}$

It was also observed that in some smiles the proportions of $70 \%$ and $90 \%$ were also considered the most attractive ones. This variability can be explained due to the subjectivity of the smile attractiveness assessment. These findings emphasize the necessity of individualization of esthetic planning for the upper anterior region. Some authors ${ }^{11-13,22}$ recommend that these results should be discussed with patients, once the preference for longer or shorter teeth, may vary among individuals. In this study, smiles images were digitally manipulated to test the esthetic perception of individuals for a certain variant. For this purpose, the proposed methodology used visual analog scales, a methodology frequently used in literature ${ }^{12,13,19,22,25,26}$ 
for it allows the use of appropriate statistical tests to compare the scores assigned to different types of smiles, as well as for the different groups of raters. Thus, the proportion of esthetic zone as a whole was altered, avoiding an excessive disproportion between central incisors, lateral incisors and canines. Besides, for the evaluation of the photographs' attractiveness, a close-up image of the smile was used, for literature does not show difference between this type of visualization and full face analysis. ${ }^{13,23}$

Another important finding was the absence of a statistically significant difference between smiles with and without display of inferior teeth. These two forms of evaluation were necessary to identify the possible influence of the presence of inferior teeth on the smile's perceived esthetic. When smile images are manipulated to created different proportions, the evaluators analyze two variants: The different proportions individually and the amount of vertical exposure of inferior teeth. This aspect can be considered a methodological bias, according reports in the literature of studies that were evaluating a single smile characteristic, and after manipulating the images, the raters end up assessing two variants of the smile, ${ }^{11-13,17,22-24}$ making the results questionable. To fix this problem, it was incorporated a black mask covering all inferior teeth to allow the individualization of proportions modification on the smile attractiveness. $\mathrm{Ker}^{24}$ found greater preference for smiles that presented deep overbite over reduced overbite ones. The data found in the present study do not confirm these findings, for the comparison between smiles with and without black mask did not present statistically significant difference, evidencing that variation in the extent of inferior teeth exposure did not affect the attractiveness of the assessed smiles.

Another important factor was the use of three smiles with different esthetic variants, that allowed evaluation of different smile components, such as wide, medium and narrow buccal corridors, teeth shapes (more squared or more rounded), and even lip thickness, from larger to thinner ones. Some studies found in literature used only one manipulated smile for the attractiveness assessment of a chosen variant. ${ }^{11,22,23,24}$ In this methodology, the results can be questioned, for the opinion will be directed to only one type of smile. On the other hand, other authors ${ }^{12,13}$ used more than one smile on their methodology. Similarly, we used three smiles to attenuate this problem and obtain further conclusions about the variant width/height proportion of teeth in the esthetic zone.

In this study, the evaluators were orthodontists and laypersons. The first group was chosen because previous researches showed that they are more strict on the identification of deviation from the ideal concept. ${ }^{11,12,22,25,26}$ The group of laypersons was chosen because they are the main consumers of dental services, instead of professionals who provide these services. ${ }^{39}$ Literature shows that orthodontists are more critical than laypersons, assigning lower scores. ${ }^{11,12,22,25,26}$ However, in most situations, our study did not find significant differences between these two groups of evaluators.

It is important to emphasize the present study assessed smiles that already had a very low level of attractiveness, due to increased level of gingival exposure $(4 \mathrm{~mm})$. The choice for this value is justified because literature shows that for different groups of individuals, smiles with this level of gingival exposure are considered non-esthetic. ${ }^{11,12,13,22}$ This aspect can be proven by the higher mean scores assigned to the smiles. Among them, the ones considered more attractive obtained means around 60 points. Thus, it can be concluded that this statistic equivalence of opinions between these groups may have been affected by this variant. In other words, the modification on teeth's width/height proportion in the esthetic zone did not affect the smile attractiveness nor affected the esthetic perception of the distinct evaluators. Besides, when evaluating laypersons' scores, it was observed high values of standard deviation, which affects the statistical analysis of comparison between groups, approaching the similarity with one another. It occurs because the attractiveness evaluation is a subjective characteristic, being more evidenced on the smile assessment by laypersons.

\section{CONCLUSION}

According to the results obtained in this research, it can be concluded that:

1) Generally, the width/height proportions of upper anterior teeth that received the highest 
scores were of $75 \%, 80 \%$ and $85 \%$ in both groups of evaluators, orthodontists and laypersons. On the other hand, the width/height proportion of upper anterior teeth of $65 \%$ received the lowest scores from the two groups of evaluators $(\mathrm{p}<0.05)$.

2) When comparing the opinion of orthodontists and laypersons regarding the three assessed smiles, it was verified that in most situations the scores in both groups did not present significant statistic difference with one another $(\mathrm{p}>0.05)$.

3) When comparing the smiles with and without display of inferior teeth, it was not observed a statistically significant difference in all situations $(\mathrm{p}>0.05)$.

\section{REFERENCES}

1. Machado AW, Santos TC, Araujo TM, Gandini Júnior LG Integração Ortodontia e Dermatologia na busca da excelência na estética labial. Rev Clín Ortodon Dental Press. 2010 Jun-Jul;9(3):47-56.

2. Hulsey CM. An esthetic evaluation of lip-teeth relationship present in the smile. Am J Orthod. 1970 Feb;57(2):132-44.

3. Legan HL, Burstone CJ. Soft tissue cephalometric analysis for orthodontic surgery. J Oral Surg. 1980 Oct;38(10):744-51.

4. Mackley RJ. An evaluation of smiles before and after orthodontic treatment. Angle Orthod. 1993;63(3):183-189.

5. Levine RA, Macguire M. The diagnosis and treatment of the gummy smile. Compend Contin Educ Dent. 1997 Aug;18(8):757-62.

6. Ahmad I. Geometric considerations in anterior dental aesthetics: restorative principles. Pract Periodontics Aesthet Dent. 1998 Sep;10(7):813-22.

7. Peck S, Peck I, Kataja, M. The gingival smile line. Angle Orthod. 1992; 62(2):91-100

8. Graber TM, Vanarsdall JR. Ortodontia: princípios e técnicas atuais. 3a ed. Rio de Janeiro: Guanabara Koogan; 2002

9. Câmara CALP. Estética em Ortodontia: Diagramas de Referências Estéticas Dentárias (DRED) e Faciais (DREF). Rev Dental Press Ortodon Ortop Facial. 2004 Nov-Dez;11(6):130-56.

10. Geron S, Atalaia W. Influence of sex on the perception of oral and smile esthetics with different gingival display and incisal plane inclination. Angle Orthod. 2005 Sep;75(5):778-84

11. Kokich VO, Kiyak HA, Shapiro PA. Comparing the perception of dentists and lay people to altered dental esthetics. J Esthetic Dent. 1999 Nov;11(6):311-24.

12. Suzuki L, Machado AW, Bittencourt MAV. Perceptions of gingival display aesthetics among orthodontists, maxillofacial surgeons and laypersons. Rev Odonto Ciênc. 2009 Jul;24(4):367-71

13. Suzuki L, Machado AW, Bittencourt MAV. An evaluation of the influence of gingival display level in the smile esthetics. Dental Press J Orthod. 2011 Sept-Oct;16(5):37.e1-10.

14. Seixas MR, Costa-Pinto RA, Araújo TM. Checklist dos aspectos estéticos a serem considerados no diagnóstico e tratamento do sorriso gengival. Dental Press J Orthod. 2011 Mar-Abr;16(2):131-57.
15. Lombardi RE. The principles of visual perception and their clinical application to denture esthetics. J Prosthet Dent. 1973 Apr;29(4):358-82.

16. Rufenacht CR. Fundamentals of esthetics. Chicago (IL): Quintessence; 1990.

17. King KL, Evans CA, Grace V, Begolle E, Obrez A. References for vertical position of the maxillary lateral incisors. World J Orthod. 2008;9(2):147-54.

18. Levin EL. Dental esthetics and golden proportion. J Prosthet Dent. 1978 Sep;40(3):244-52.

19. Maple JR, Vig KW, Beck FM, Larsen PE, Shanker S. A comparison of providers' and consumers' perceptions of facial-profile attractiveness. Am J Orthod Dentofacial Orthop. 2005 Dec;128(6):690-96.

20. Simon Z, Rosenblatt A, Dorfman W. Eliminating a gummy smile with surgical lip repositioning. J Cosmetic Dentistry. 2007;1(23):100-8

21. Polo M. Botulinum toxin type $A$ in the treatment of excessive gingival display. Am Orthod Dentofacial Orthop. 2008 Feb;133(2):195-203.

22. Kokich VO, Kokich VG, Kiyak HA. Perceptions of dental professionals and laypersons to altered dental esthetics: asymmetric and symmetric situations. Am J Orthod Dentofacial Orthop. 2006 Aug;130(2):141-51.

23. Rodrigues CDP, Magnani R, Machado MS, Oliveira OB. The perception of smile attractiveness. Angle Orthod. 2009 Jul;79(4)4:634-9.

24. Ker AJ, Chan R, Fields HW, Beck M, Rosenstiel S. Esthetics and smile characteristics from the layperson's perspective: a computer-based survey study. J Am Dent Assoc. 2008 Oct;139(10):1318-27.

25. Parekh SM, Fields HW, Beck M, Rosenstiel S. Attractiveness of variations in the smile arc and buccal corridor space as judged by orthodontists and laymen. Angle Orthod. 2006 Jul; 76(4):557-63.

26. Pinho S, Ciriaco C, Faber J, Lanza MA. Impact of dental asymmetries on the perception of smile esthetics. Am J Orthod Dentofacial Orthop. 2007 Dec:132(6):748-53. 